\title{
PRESENT DAY STATUS AND FUTURE OF NATURE CONSERVATION IN THE REPUBLIC OF MALAŴI
}

\author{
D G ANSTEY and A J HALL-MARTIN
}

Department of National Parks and Wildlife

Lilongwe and Wildlife Research Unit

Kasungu

Malaŵi

\section{Introduction}

When Malawii (formerly Nyasaland) became independent in 1964 the status and future of its game reserves were in jeopardy. The former administration had adopted a policy of benign neglect towards the country's wildlife areas (Anon 1963), and the remnants of the Department of Game, Fish and Tsetse Control had been absorbed by the Forestry Department in 1963. Fortunately the Life President of Malawii, Dr H Kamuzu Banda, took a strong interest in wildlife conservation and it was only his personal intervention, and the advent of independence, that saved the former Lengwe Game Reserve from deproclamation (Hayes 1967) as planned by the colonial administration. With the Life President's encouragement and the dedicated efforts of the staff responsible for wildlife, the tide which had been running strongly against nature conservation was turned, culminating in the establishment of a separate Department of National Parks and Wildlife only a decade after independence.

\section{Physiography and climate}

The Republic of Malawi (RM) lies in south-east central Africa between $9^{\circ} 25^{\prime}$ and $17^{\circ} 08^{\prime} \mathrm{S}$ and $33^{\circ}$ and $36^{\circ} \mathrm{E}$. Its total area is $121600 \mathrm{~km}^{2}$ which includes $28416 \mathrm{~km}^{2}$ of surface water (Lakes Malawi, Chilwa and Malombe). The country has borders with Mocambique, Tanzania and Zambia (Fig. 1) and is totally landlocked. The Great Rift Valley in which Lakes Malawi and Malombe lie traverses the country from north to south. These lakes are drained by the Shire River which follows the Rift Valley to the Zambesi River. The Rift Valley plains lie at altitudes of $100-450 \mathrm{~m}$ and are separated from the Central African Miocene peneplain surface by the escarpments which form the walls of the Rift Valley. The peneplain surface lies at an altitude of $600-1500 \mathrm{~m}$ and forms the greater part of the country. Isolated granite inselbergs and mountains rise above the plain to altitudes of $3001 \mathrm{~m}$ (Mlanje), $2087 \mathrm{~m}$ 


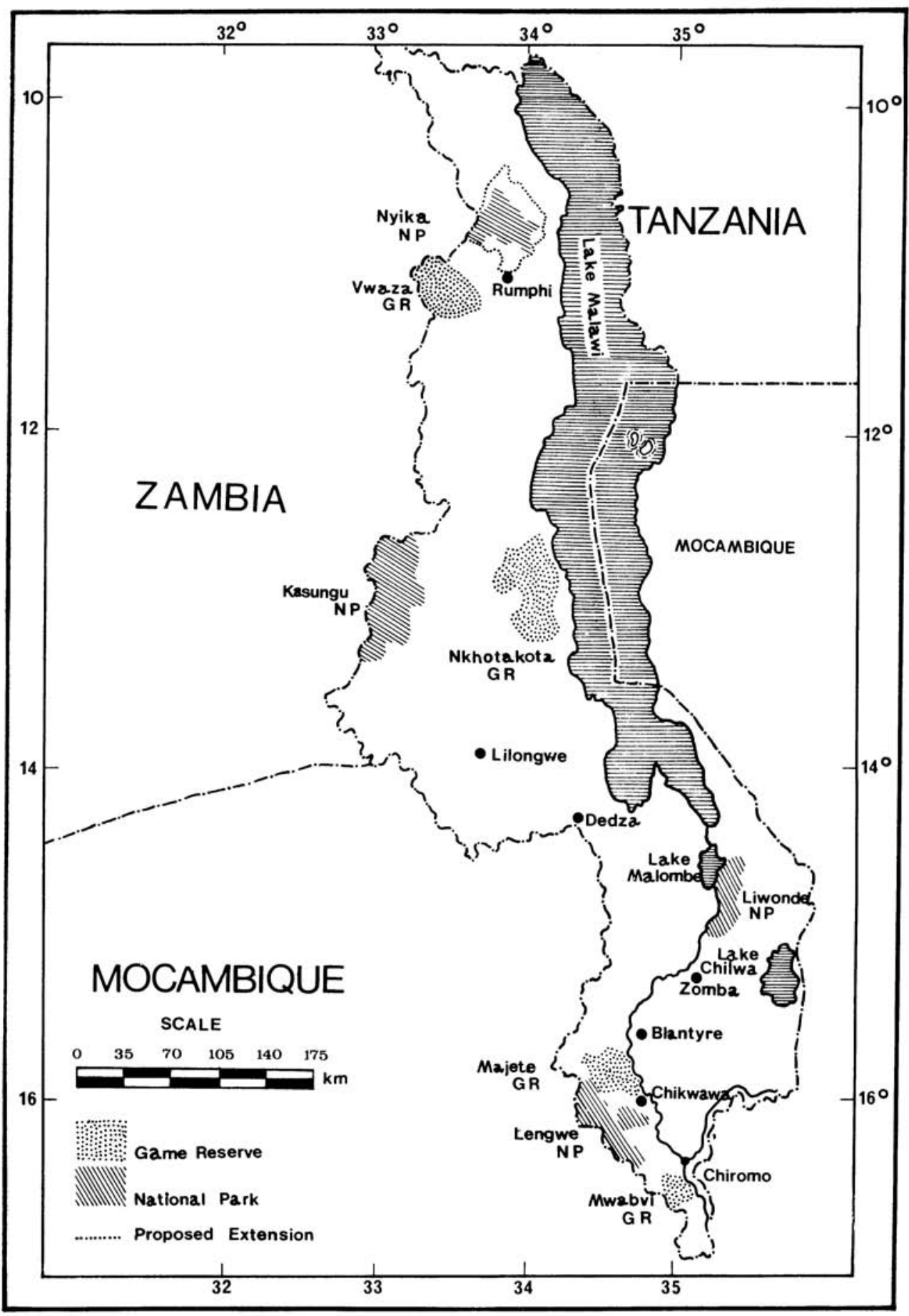

Fig. 1. Republic of Malawi showing the distribution of National Parks and Game Reserves. 
(Zomba) and $2260 \mathrm{~m}$ (Dedza) while in the north of the country the high montane plateaux of the Nyika (2 $606 \mathrm{~m})$, Vipya (2 $082 \mathrm{~m})$ and Misuku $(1859 \mathrm{~m})$ cover large areas. These montane areas are believed to be the remnants of the late Jurassic peneplain (Chapman 1968). These three major physiographic regions exert a major influence on the vegetation types.

The climate of the RM is partly continental in character (Griffiths 1972) but the physiographic regions and the proximity of the Indian Ocean have a great effect on rainfall and temperature and there is considerable local variation. The Rift Valley areas are generally hot with maximum temperatures commonly reaching $45^{\circ} \mathrm{C}$ (Hall-Martin 1975), but with a mean annual temperature of $18^{\circ} \mathrm{C}-24^{\circ} \mathrm{C}$, whilst the mountain plateaux have a mean annual temperature below $19^{\circ} \mathrm{C}$ with frequent frosts during the winter months (Chapman 1968). Rainfall varies from $500-1125 \mathrm{~mm}$ per annum over most of the country but is much higher where topographic features play a role, such as the northern shores of Lake Malawi and on mountain slopes which intercept rainbearing winds. On Mount Mlanje, for example, the rainfall reaches 2000 millimeters. There is a clearly defined seasonal rhythm in rainfall and temperature resulting in a wet season from November to April, and a dry season from May to October. A feature of the dry season climate is the regular invasion of moist maritime air from the Mocambique Channel resulting in periods of cool, overcast and drizzling weather.

\section{Vegetation}

The vegetation of the RM has been described by various authors (Wild and Barbosa 1967; Brass 1953; Chapman 1962, 1968; Chapman and White 1970; Jackson 1954; Hall-Martin 1972, 1975). As a result the distribution of the most important vegetation types is now known, as also the occurrence of many rare and endangered species.

The greater part of the Miocene surface is covered in dense to open miombo woodland composed largely of members of the broad-leaved deciduous genera Brachystegia, Julbernardia and Isoberlinia. Drainage lines in these woodlands are usually edaphic grasslands, known locally as "dambos". In the lower lying areas of the peneplain surface the miombo gives way to a deciduous tree savanna in which the principal woody plants are Pterocarpus angolensis, Combretum spp, Pericopsis angolensis, Terminalia sericea, Burkea africana and Ostryoderris stuhlmanii and several Acacia species. On the escarpment areas and the upper Rift Valley plains dry deciduous tree savanna and woodland dominated by Colophospermum mopane with a grass layer composed largely of the genera Eragrostis, Cenchrus, Schmidtia and Aristida occurs. The floor of the Rift Valley is covered by a deciduous tree savanna dominated by Adansonia digitata, Sterculia appendiculata, Kirkia acuminata, Cordyla africana and Acacia nigrescens. The most important grasses are Panicum maximum, Urochloa mossam- 
bicensis and Digitaria milanjiana. In most areas the river banks and termite mounds support forest or thickets. Areas along the lake shores and major river valleys support swamp grasslands; Cyperus papyrus and Phragmites mauritianus beds; and the palms Hyphaene and Borassus are common in wetter areas.

The other major plant formations of the $\mathrm{RM}$ are those associated with the montane areas. Broad-leaved evergreen forest is distributed in patches on all the higher inselbergs and mountains and consists of many types often dominated by Ocotea usambarensis, Chrysophyllum gorungosanum, Strombosia scheffleri, Drypetes gerrardii and Aningeria adolf-friederici. At high altitudes conifer forest is also found but is confined to the Nyika plateau where the dominant species is Juniperus procera and on Mt Mlanje where Widdringtonia whytei is dominant and stands $50 \mathrm{~m}$ tall. Montane grasslands dominated by Exotheca abyssinica, Loudetia simplex and Monocymbium ceresiiforme are present on all high mountain plateaux.

There are also many other vegetation types in Malawi which are less widespread such as lowland evergreen forest, lowland dry deciduous forest and thicket and many lesser savanna and woodland types.

\section{Human population}

The population of the RM in 1976 is estimated at 5000000 , living at a density of 67 per km² with local densities of 309 per km² (Anon 1963). The people are mostly agriculturalists but a transition to an industrialised society is taking place rapidly.

\section{Nature conservation legislation}

National parks and game reserves in the RM are authorised and managed largely in compliance with three government acts. The Land Act authorizes acquisition of customary land and its declaration as Public Land which can then be gazetted as a National Park. The Game Act (1954) prescribes a means for establishing game reserves and identifies activities which are prohibited in game reserves. The National Park Act (1969) provides the most comprehensive control order over activities within any area of the Department of National Parks and Wildlife. A significant inclusion of the National Park Bill is that no national park may be reduced in area without a specific resolution of parliament. A new comprehensive Flora and Fauna Act is in draft stage. This Law will supercede the Game Act, and will provide the authority for stricter protection outside the parks.

\section{Parks and reserve administration}

From 1963 to 1973, the national parks and game reserves were the responsibility of the Game Division of the Department of Forestry and 
Game. In April 1973, at the direction of the Life President of Malawii, a separate Department of National Parks and Wildlife was established within the Ministry of Agriculture and Natural Resources. This Department now manages four national parks, three established game reserves and one proposed game reserve. Crop protection and control of other problem animals outside the parks and game reserves is also the responsibility of the Department.

The Department of National Parks and Wildlife is headed by a Principal Warden who is responsible to the Secretary for Agriculture and Natural Resources. Consistent with the three administrative divisions of the RM, three Regional Wardens supervise Department activities in these Regions. A Senior Warden is in charge of each of the four national parks. The conservation force presently consists of 17 Rangers, 15 Head Scouts and 108 Scouts distributed throughout the eight areas. There is also a Crop Protection Unit within the Department headed by a Crop Protection Officer. This unit deals with marauding wild animals and has 20 supporting staff. A Wildlife Research Unit is situated in the Kasungu National Park. A Conservation Sanctuary and a Research and Monitoring Unit has been set up in the Nyika National Park. A Conservation Sanctuary and Education Centre has been set up on 100 ha of old Forest Reserve within the new Lilongwe Capital City. This will be the focus of conservation education activities of the Department.

Three of the National Parks (Lengwe, Kasungu and Nyika) have overnight visitor facilities and are open to the public. The fourth Park (Liwonde), gazetted in 1972, is expected to be opened in 1977. The game reserves are being managed on a care and maintenance basis. However, their potential for eventual utilization is being investigated.

While making provisions for visitor use in the national parks, the government's first concern is to perpetuate the parks and game reserves as biotic reserves. The Department's management of each area reflects this emphasis. The Department maintains contact with relevant organisations at the national and international level and in particular is an active participant in the activities of the Southern African Regional Commission for the Conservation and Utilization of the Soil (SARCCUS) and the Eastern African Wildlife and National Parks annual meetings.

Much of the impetus for national park development and wildlife conservation in the RM has been due to the personal interest demonstrated by H.E. the Life President. Material assistance has also been received from the National Fauna Preservation Society of Malawi (formerly the Nyasaland Fauna Preservation Society) - whose crucial role in many early developments is chronicled by Hayes 1974, the World Wildlife Fund, the Frankfurt Zoological Society, the African Wildlife Leadership Foundation and the SA Nature Foundation. The assistance of the latter organization was of particular importance to the establishment of the Wildlife Research Unit in 1969. The Research and 
Monitoring Unit in the Nyika National Park has been set up with Canadian funds. However, the main donor has been the British Government which has provided $\mathrm{K} 670000(\mathrm{Kl}=\mathrm{R} 1)$ to date, while the Malawi Government provides K270 000 each year. Training of Malawian rangers has been undertaken at Mweka College in Tanzania with the support of FAO and more recently at Cwaka College in Kwa Zulu, South Africa.

\section{The national parks and game reserves}

The total area falling under the protection of the National Parks Act (1969) or the Game Act (1954) is $10426 \mathrm{~km}^{2}$ or roughly $8,6 \%$ of the total surface area of the RM. In addition to this a further $7770 \mathrm{~km}^{2}$ $(6,4 \%$ of total surface area) is protected or partly protected as forest reserve.

Some details of national parks and game reserves are as follows:

Nyika National Park - 304385 ha (figure includes extensions to the park which have been approved but are not yet gazetted)

This park includes virtually the whole of the famous Nyika plateau $(1830-2606 \mathrm{~m})$ and its escarpment slopes. The main vegetation types protected are extensive montane grasslands, broad-leaved evergreen forest on the plateau and escarpment including Entandophragma excelsum montane forest and Ocotea/Ficalhoa montane forest, Phillipia benguelensis communities, Protea communities, transitional Brachystegia woodlands on the escarpment slopes and conifer forest dominated by Juniperus procera. These small patches of junipers and Hagenia abyssinica are here at the southern limits of their range, Ternstroemia polypetala is only known from the Nyika in the Flora Zambesiaca area (Chapman 1968). The Nyika is also the type locality of many plants, birds, reptiles and mammals. Among the most interesting mammals occurring in the park are the roan antelope Hippotragus equinus, Crawshay's zebra Equus burchelli crawshayii, Livingstone's eland Taurotragus oryx livingstonii, common reedbuck $R e-$ dunca arundinum, grey duiker Sylvicapra grimmia, bushbuck Tragelaphus scriptus, leopard Panthera pardus, side-striped jackal Canis adustus, chequered elephant shrew Rhyncocyon cirnei. Nyasa red and black squirrel Heliosciurus lucifer, tree hyrax Dendrohyrax arboreus, klipspringer Oreotragus oreotragus, spotted hyaena Crocuta crocuta and Nchima monkey Cercopithecus mitis. Planned extensions to the park will include greater areas of escarpment slopes and Brachystegia woodlands resulting in increases in numbers of those migratory species which move off the plateau annually. Buffalo Syncerus caffer and elephant Loxodonta africana which occur in the northern extension will then be added to the fauna of the park. 
Kasungu National Park - 220320 ha

This park lies on the Miocene surface of central Malawi and consists of generally flat landscape with inselbergs. The predominant vegetation is miombo woodland (Brachystegia - Julbernardia - Isoberlinia), with dambo grasslands. Deciduous tree savanna with Terminalia sericea, Combretum spp, Strychnos spp and Acacia spp dominant, and Echinochloa pyramidalis, Imperata cylindrica grasslands in suitable localities are also important. The most common mammals are elephant, buffalo, Lichtenstein's hartebeest Alcelaphus lichtensteinii, sable Hippotragus niger, zebra E.b. selousi, roan, reedbuck, oribi Ourebia ourebi, lion Panthera leo, leopard, spotted hyaena, grey duiker, Sharpe's grysbok Raphicerus sharpei, waterbuck Kobus ellipsiprymnus and warthog Phacochoerus aethiopicus. There are also small populations of black rhinoceros Diceros bicornis, cheetah Acinonyx jubatus and Johnstone's impala Aepyceros melampus johnstonii.

Lengwe National Park - 90720 ha (figure includes extensions to the park which have been approved but are not yet gazetted).

Situated on the floor of the Rift Valley this Park supports representatives of all the Rift Valley vegetation types except aquatic and hygrophilous types. The most important communities are Newtonia hildebrandtii/Pterocarpus antunesii dry deciduous forest and thickets, Acacia nigrescens savanna and woodland, Dalbergia melanoxylon tree savanna, Hyphaene ventricosa palm savanna, Combretum apiculatum savanna and Colophospermum mopane woodland. The approved extension will add Brachystegia and Pterocarpus angolensis woodlands to the park. A total of 36 plant species collected in the park have not yet been found elsewhere in Malawi, and includes endemics of the Shire/Zambesi lowlands such as Cola mossambicensis.

The dry forest and thickets are particularly important as the habitat of the northern-most population of nyala Tragelaphus angasi in Africa (numbering $1500-2000$ ), and the park also supports suni Nesotragus moschatus, bushbuck, bushpig Potamochoerus porcus, Nchima monkey, chequered elephant shrew, four-toed elephant shrew Petrodromus tetradactylus, kudu Tragelaphus strepsiceros, impala, buffalo, spotted hyaena, leopard, warthog, sable and roan antelope. This park is also the only known locality of the recently described mollusc Rachis cunctatoris (Van Bruggen 1975) which was collected for the first time in 1970 by one of us (A.J.H-M).

\section{Liwonde National Park - 58616 ha}

This is the newest park in the RM and contains representative vegetation types of the Rift Valley including reedbeds, papyrus swamp, palm savanna, Colophospermum mopane woodland (with individual trees taller than $30 \mathrm{~m}$ ), Piliostigma savanna, Brachystegia woodland and dry forest. The most important large mammals are elephant, hippopotamus Hip- 
popotamus amphibius. sable, kudu and duiker. This is the only park in Malawi which contains crocodiles Crocodylus niloticus, and which lies within the historical range of Johnstone's wildebeest Connochaetes taurinus johnstonii. which has been extinct in Malawi since 1925. This park includes both banks of the Shire River and is therefore of great importance as protected examples of this biome are rare in Malawi.

\section{Vwaza Marsh (proposed) Game Reserve - 103680 ha}

The Vwaza Marsh lies at the foot of the Nyika Plateau from where it derives most of its water. The predominant vegetation of the marsh itself is a saline swamp grassland with woody plants restricted to thickets on termite mounds perched above seasonal flood levels. Surrounding the marsh is extensive Brachystegia woodlands, Colophospermum mopane woodlands (at the extreme northern limit of its range), deciduous thicket and Piliostigma/Acacia tree savanna. This area still supports viable populations of elephant, buffalo, hippo and several species of antelopes.

\section{Nkhotakota Game Reserve - 174960 ha}

The reserve occupies the escarpment between the Miocene plain and the Rift and the vegetation is predominantly miombo woodland. On the slopes of Chipata, an inselberg on the edge of the escarpment a small patch of montane forest is protected. The reserve has numbers of elephant, zebra, sable, bushbuck and small animals. Black rhino were exterminated in the area as recently as the 1950's. However, with its great scenic beauty this reserve is ideally suited for walking trail utilization.

\section{Majete Game Reserve - 64000 ha}

This reserve also occupies the transitional area extending from the Miocene surface down to the Shire River on the floor of the Rift Valley. The vegetation types are varied and include Brachystegia woodlands, Terminalia sericea tree savanna, Pterocarpus angolensis savanna, Colophospermum mopane woodland and riverine thicket and forest, small populations of elephant, eland, waterbuck and other antelopes still inhabit the area.

\section{Mwabvi Game Reserve - 25920 ha}

This is the smallest of the game reserves but perhaps one of the most important in the RM and occupies the edge of the Rift Valley. Most of its vegetation types are also found in the Lengwe National Park and these include Colophospermum mopane woodland, Acacia nigrescens savanna and extensive dry forest and thickets. This reserve is most important as a sanctuary for black rhinoceros, nyala and suni and as part of the Lower Shire Valley Eastern Escarpment Conservation Plan of the I.D.A. Development Project. 
As is evident from the above review, most of the major vegetation types of the RM are adequately represented in the national parks and game reserves. Several types of broad-leaved evergreen forest as well as Widdringtonia whytei forest and several miombo types, and a few endemic or endangered species such as Burtdavya nyassica do not occur in game reserves or parks. However, most of these occur in forest reserves where they are presently adequately protected. There are few, if any, vegetation types which are not therefore protected in some way - a situation which is probably unique in Africa. All the extant large mammals are also found in the sanctuaries. Only one large mammal has become extinct in Malawi during this century namely the Johnstone's wildebeest. The puku Kobus vardoni occurred in large numbers on the Bua and Rusa floodplains in central Malawi. Excessive hunting led to its disappearance by 1958. However, since 1971 several individuals, originating from Zambia, have on occasions been sighted in Kasungu National Park. There are also records of the occurence of Cookson's wildebeest C.t. cooksonii in the Kasungu area this century and isolated individuals have also recently been sighted in the park.

\section{Future prospects}

Under the enlightened leadership of H.E. the Life President great strides have been made in nature conservation in the 12 years since independence. During this time the total land area under protection (other than forestry lands) has been increased from $5732 \mathrm{~km}^{2}$ to $10426 \mathrm{~km}^{2}$ or by 82 per cent. Seeing that most biotic communities are now represented in parks or reserves, the tempo of increase of these areas will probably decline in the future. The major systems still requiring representative protection are some of the vegetation types which occur north of the Nyika and the aquatic biomes. However, a national park to protect a sample of lacustrine environment has been approved in principle and will be established in 1977. This park will play a vital role in the conservation of the large number of species of Cichlids used in the tropical fish trade. It will also be the only biotic reserve covering a deep water lake environment in Africa. The park will also be of particular interest as Lake Malawi has the highest rate of endemism among its fishes of any lake in the world with 223 out of 250 species $(89 \%)$ endemic (Beadle 1974).

Of the larger mammals which can be regarded as endangered are the black rhino (with small populations in Kasungu and Mwabvi), the cheetah (small population in Kasungu), the wild dog Lycaon pictus (possibly only vagrants from Zambia occur in the Kasungu National Park), the puku and Cookson's wildebeest (isolated individuals in Kasungu) and the pangolin Manis temmincki which is rare in Malawi. In the case of the rhino and cheetah adequate areas of suitable habitat are now protected, but probably none of the parks are large enough to 
support a viable wild dog population. The crocodile is also endangered outside the Liwonde National Park. The flying squirrel Anomalurus derbianus is the only mammal known to occur outside protected wildlife areas - but it is found in forest reserves in northern Malawi.

Having created a viable Department of National Parks and Wildlife which can cater for most of the conservation needs of the country the priority of the Malawi Government is now to consolidate the Department and to develop the existing parks and reserves to their best potential for both conservation and utilization on the basis of practical applied research coupled with a constant environmental monitoring programme.

\section{REFERENCES}

ANON, 1963. Note on the problems surrounding the implementation of a wild life utilization policy in a densely populated country. In: Conservation of Nature and Natural Resources in modern African States. I.U.C.N. Publications. New series No. 1: 250-252.

BEADLE, L C 1974. The Inland waters of Tropical Africa. London: Longman.

BRASS, L J 1953. Vegetation of Nyasaland. Report on the Vernay-Nyasaland Expedition of 1946. Mem. N.Y. Bot. Gard. 8(3).

CHAPMAN, J D 1962. The vegetation of the Mlanje Mountains. Nyasaland. Zomba: Govt. Pr.

CHAPMAN, J D 1968. Malawi. In: Conservation of vegetation in Africa south of the Sahara. Acta. Phytogeogr. Suec. 54: 215-224.

CHAPMAN J D and F WHITE. 1970. The evergreen forests of Malâ̂i. Comm. Forestry Inst., Univ. of Oxford.

GRIFFITHS, Y F 1972 (ed). Climates of Africa. World Survey of Climatology. Vol. 10.

HALL-MARTIN, A J 1972. Aspects of the plant ecology of the Lengwe National Park. Malawii. M.Sc. Thesis, Univ. of Pretoria.

HALL-MARTIN, A J 1975. Classification and ordination of forest and thicket vegetation of the Lengwe National Park, Malawi. Kirkia 10(1): 131-184.

HAYES, G D 1967. How independence saved an African reserve. Oryx 9: 24-27.

HAYES, G D 1974. Conservation in Malawi - old and new. Oryx 12: 334-340.

JACKSON, G 1954. Preliminary ecological survey of Nyasaland. Proc. 2nd. Inter. Afr. Soils Conf. Leopoldville: 679-690.

VAN BRUGGEN, A C 1975. New taxa of Streptaxidae and Enidae (Mollusca Gastropoda Pulmonata) from South Africa and Malaŵi. Zool. Meded. Leiden. 49: 207-223.

WILD, $\mathrm{H}$ and L A GRANDVAUX BARBOSA. 1967. Vegetation map of the Flora Zambesiaca area. Salisbury: Collins. 